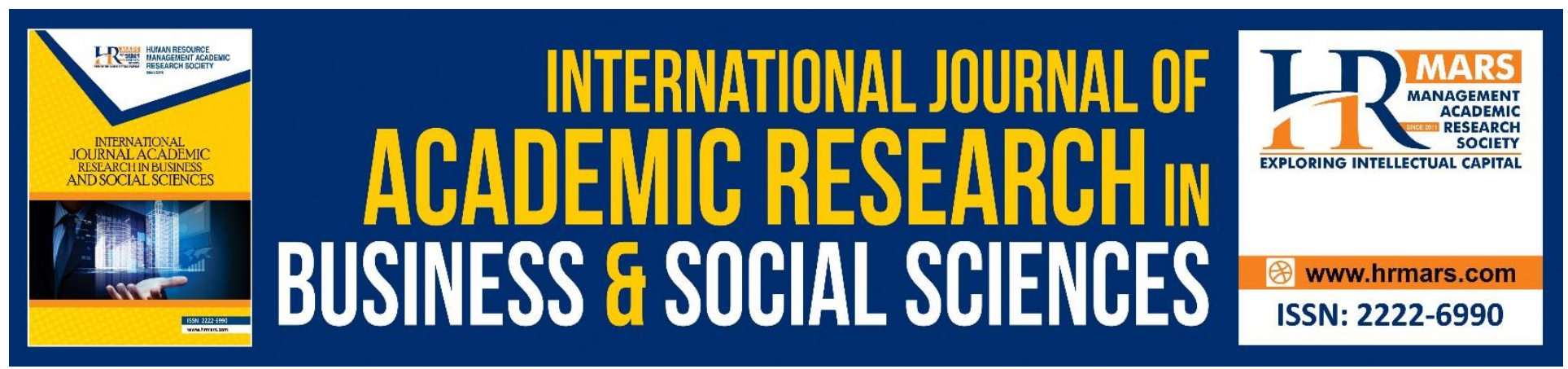

\title{
The Just War Theory: Accounting Jus Post Bellum
}

Mohd Rizal Yaakop, Sharifah Aluya Ali, Sharifah Sabrina Ali, ling Nurdin, Farhatul Mustamirah, Ahmad Ali Seman, Ahmad Redzuan Mohamad and Mohd Azmi Mohd Razif

To Link this Article: http://dx.doi.org/10.6007/IJARBSS/v10-i8/7667

DOI:10.6007/IJARBSS/v10-i8/7667

Received: 22 May 2020, Revised: 24 June 2020, Accepted: 21 July 2020

Published Online: 29 August 2020

In-Text Citation: (Yaakop, Ali, Ali, Nurdin, Mustamirah, Seman, Mohamad, and Razif, 2020).

To Cite this Article: Yaakop, M. R., Ali, S. A., Ali, S. S., Nurdin, I., Mustamirah, F., Seman, A. A., Mohamad, A. R., and Razif, M. A. M. (2020). The Just War Theory: Accounting Jus Post Bellum. International Journal of Academic Research in Business and Social Sciences. 10(8), 962-978.

Copyright: (C) 2020 The Author(s)

Published by Human Resource Management Academic Research Society (www.hrmars.com)

This article is published under the Creative Commons Attribution (CC BY 4.0) license. Anyone may reproduce, distribute, translate and create derivative works of this article (for both commercial and non-commercial purposes), subject to full attribution to the original publication and authors. The full terms of this license may be seen

at: http://creativecommons.org/licences/by/4.0/legalcode

Vol. 10, No. 8, 2020, Pg. 962 - 978

Full Terms \& Conditions of access and use can be found at http://hrmars.com/index.php/pages/detail/publication-ethics 


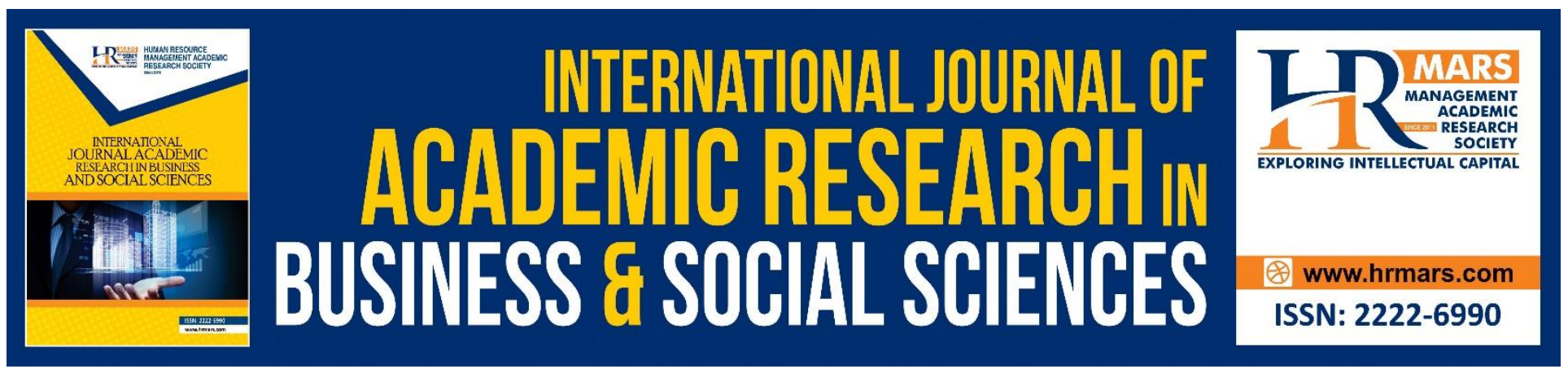

\section{The Just War Theory: Accounting Jus Post Bellum}

\section{Mohd Rizal Yaakop, Sharifah Aluya Ali and Sharifah Sabrina Ali, ling Nurdin, Farhatul Mustamirah, Ahmad Ali Seman, Ahmad Redzuan Mohamad and Mohd Azmi Mohd Razif}

Faculty of Social Sciences and Humanities, Universiti Kebangsaan Malaysia, 43600, Bangi, Selangor,

Malaysia, Universiti Malaysia Sarawak (UNIMAS), Universitas Jenderal Ahmad Yani Indonesia Faculty of Social Sciences and Humanities, Universiti Kebangsaan Malaysia, 43600, Bangi, Selangor, Malaysia, Faculty of Social Sciences and Humanities, Universiti Kebangsaan Malaysia, 43600, Bangi, Selangor, Malaysia, Islamic Science Institute, Islamic Science University of Malaysia, Nilai, 71800, Negeri Sembilan, Malaysia

Email: rizaly@ukm.edu.my, aluyariz@hotmail.com,nurdiniing12@gmail.com, aasw@ukm.edu.my redzumark@gmail.com, azraz910@gmail.com

\section{Abstract}

A Just War Theory is a moral doctrine about the use of force. It underlines certain basic principles of waging war, starting from the intention to wage war until the conduct of soldiers during war, known to be jus ad bellum ( the resort to war), jus in bello ( the actual conduct of war), and the most recent development jus post bellum ( justice after war). As propagated, Just War Theory legitimized the use of force as long as all the requirements of its principles has been fulfilled; first is the principle of jus ad bellum lays the justifying requirements for why war is waged, namely just cause, legitimate authority, right intention, proportionality, probability of success and war as the last resort. Second is the principle of jus in bello, the justifying principle governing the conduct within war, namely proportionality, right intention as well as the issue of noncombatant immunity

Keyword: Just War Theory, Conflict.

\section{Introduction}

To many individuals, political scientists as well as laymen, the phrase "Just War" appears to be a contradiction in terms. The effort of establishing rules and regulations by which men intentionally and systematically kill other human beings is continually questioned and heavily criticized.

War as a social phenomenon, has been defined as "a fight between human societies, in primitive conditions between savage tribes, in the civilized world between states" (Joachim, 1939). Ever since history has recorded the activities of organized groups, war has been one of its principal topics. The outcome of war is brutal and tragic despite whether it served the purpose of its initiator or not. War should be undertaken as infrequently and humanely as possible. Yet, war is also, at times, 
necessary. Thus the employment of force needs to be limited by accepted moral principles, the Just War Theory.

Critics of Just War Theory often ask a penetrating question of if one is abhorred by war, why outline principles that seek to morally justify it. Just war theorists share with realists the basic assumption that international life is essentially anarchic and dangerous. Unfortunately, war is a central feature of human civilization and will occur in spite of our continuous efforts to prevent it. The critical reality makes it necessary to adopt moral guidelines limiting the use of force for those who would undertake it.

The creation of the United Nations as an intergovernmental organization in 1945 has paved way for more integrated cooperation among nation states. One of the main objectives of the United Nations is to protect the security of the international community in hope to bring peace after the sufferings of two world wars. Rapid development of modern warfare has challenged not only the reliability of the UN but also challenged the traditional view on war and peace itself. Peace is often viewed as the condition where there is no war but the reality dictates that the absence of war does not mean that there is peace. The UN is now facing a new threat to the security of the international system that is a threat coming from those nations relapse to the cycle of conflict due to mismanagement of postconflict justice such as Afghanistan and Iraq.

As the sources of the international law on the use of force, jus ad bellum and jus in bello have for centuries been guiding the use of force starting from waging war to guiding the process of war until the 'just' objective of the war is achieved. What happened after the war, which is the post-conflict reconstruction, is always an afterthought whereas it should be included in the systematic formulation before the war is waged in order to save succeeding generations from the scourge of war. Jus post bellum has never been given any attention but the recent upturn of events of terrorism which has its roots coming from those countries left in shambles after war has turned the debates on the necessity of jus post bellum and just peace as the main element of post-conflict justice.

The objectives of this study is to examine Just War Theory, the origin and its development.

\section{Just War Theory}

Just War Theory is a singular theory of justice as it relates to war has developed with enough consistency that it has become a tradition. The emphasis here is justice. The importance of justice to human being is overwhelmingly apparent. However the very meaning of justice is always disputed. The philosopher Walzer (2006), referring to the various interpretations of justice, calls its ambiguity an "anarchy of moral meanings". Before asking what is just it is best first to explore the two principle meaning of justice.

Aristotle called justice "the very criterion of what is right" (Herman and Osborn, 1942). This is a well-known but vague definition as to what is right? Kant said that from the beginning of human history "some form of civil government and public justice began...From this first, crude structure, all human arts, of which sociability and civil security are the most worthwhile, could gradually develop..." (Cummiskey, 2008). Rawls (1999) calls justice "the first virtue of social institutions, as truth is of systems of thought". Morgenthau (1970) in his book Truth and Power (1970) acknowledged, "To do justice and to receive it is an elemental aspiration of man". Hence no matter on what side of the distinction between the two types of justice one may fall, justice is nevertheless the cornerstone of ethical thought. 
INTERNATIONAL JOURNAL OF ACADEMIC RESEARCH IN BUSINESS AND SOCIAL SCIENCES Vol. 10, No. 8, 2020, E-ISSN: 2222-6990 @ 2020 HRMARS

The element of just or justice imbedded on the Doctrine of Just War Theory should be elaborated thoroughly so that we can understand its application through its main principles that will be highlighted later in this paper. Rawl's theory of justice in his book $A$ Theory of Justice calls justice as "the first virtue of social institutions, as truth is the systems of thought" (Rawl, 1999). In this context, Rawls (1999) emphasizes that justice should (1) guarantee the right of each person to have the most extensive basic liberty of others and (2) social and economic positions are to be to everyone's advantage and open to all. Rawls also states that an injustice is tolerable only when it is necessary to avoid an even greater injustice.

Now having to elaborate the definition of justice by various other philosophers, it is best that we revert back our attention to the man of our analysis, Thomas Aquinas. Justice has been discussed in great length in Aquinas' theory of natural law. Aquinas (Dierksmeier and Celano, 2014) holds that the "natural light "of reason ultimately leads to truth. In Aquinas views, the human being is endowed with rational capacities sufficient for earthly life; they may be supervened but are not contradicted or annihilated by 'supernatural', for example revelation-based knowledge (Dierksmeier and Celano, 2014). Revelation-based knowledge urges studying the world in its own light, that is, uncovering the laws of nature as they show themselves to natural reason, honours God, he argues, because through creation we learn indirectly about its Creator (Dierksmeier and Celano, 2014). He later emphasizes that true faith ought to be based upon worldly knowledge, since God chose to reveal himself also in and through His creation. The basic tenets of theoretical philosophy can be known solely by reason, and the same holds for the fundamentals of moral reasoning.

According to Aquinas, God's governance of the universe through "divine reason" proceeds in ordering everything towards the good through eternal law (Dierksmeier and Celano, 2014). Aquinas put a lot of faith in human reasoning that will incline to do good and avoid evil. It is indeed idealistic view of human, neglecting the bad side of free thinking. In upholding human reasoning capacity as the main mechanism to differentiate between right and wrong without any check and balance mechanism is both risky and foolish. To make it simple, good for one does not mean it is good for all. To continue on Aquinas, he stated that human life receives an elevated status because human intellect can be cognizant of the order that governs life by recognizing the natural laws of both human and sub-human life (Elshtein, 2004). Aquinas further explains that

"... human reason can understand how natural laws orient all beings towards their good which when realized perfects them. Unlike animals, however, human beings cannot rely solely on natural instincts to achieve their good. Aquinas explains that as being acting upon rational conception about the world, human needs to represent to themselves the goals (as objectives) they are to pursue; they need to make the implicit law that governs their lives explicit." (Elshtein, 2004)

According to (Dierksmeier and Celano, 2014) human needs specific cultural forms in order to articulate ethical norms. Moral insight advances through the unification of three different levels of ethical understanding:

1) A principled insight that good is to be pursued and evil to be avoided

2) A situational judgment that informs which kind of behaviour meets the criteria of law, custom and virtue that specify the good in each concrete context

3) Knowledge that identifies the specific factual nature of the case at hand

The general principle of basic goods of human life is "to do good and to avoid evil". To do good is natural goods for example like preservation, procreation, social responsibility and spiritual growth while to avoid evil means that one should do no harm to no one. 
INTERNATIONAL JOURNAL OF ACADEMIC RESEARCH IN BUSINESS AND SOCIAL SCIENCES Vol. 10, No. 8, 2020, E-ISSN: 2222-6990 @ 2020 HRMARS

Having to discuss Thomas Aquinas' natural law, we should now have at least a basic understanding on what is justice. Aquinas defined justice as "a habit according to which one gives to everyone what is right with a constant and perpetual will" (Dierksmeier and Celano, 2014). Thus the extension of the individual virtue of justice into societal dimensions expresses a need for certain forms of institutional, for example legal and justice.

Now let us focus our attention on Just War Theory or Just War Tradition. Campbell (2007) emphasized in his writing that it is important to distinguish between two different but often confused terms; Just War Theory and the Just War Tradition; in which a Just War theory is a moral doctrine about the use of force; theories are the most widely cited. Just War theories can take many forms: secular, divine, legal, philosophical, and so on.

By contrast, the Just War tradition is the sum of the multifaceted theories and is fragmented and dominated by none in particular (Walzer, 2006). Walzer (2006) conceptualizes the heart of the just war tradition as "a set of articulated norms, customs, professional codes, legal precepts, religious and philosophical principles and reciprocal arrangements, that shape our judgment of military conduct".

\section{Historical Progress of Just War Theory}

The Just War tradition has a rich history that has evolved over the centuries and represents a mixture of many different just war theories. Bellamy (2006) describes the just war tradition as a protracted normative conversation about legitimacy in the use of force which has been "adapted and refined by numerous subsequent commentators, each advancing related but distinct normative theories about the ethics of war". The results of centuries of conversation are that the tradition has crystallized around a number of accepted principles and theories:

a) Jus ad bellum: the resort to war

b) Jus in bello: the actual conduct of war

c) Just post bellum: justice after war

Critics of just war often ask a penetrating question: "If one is abhorred by war, why outline principles that seek to morally justify it?". Just war theorists share with realists the ontological assumption that international life is essentially anarchic and dangerous. Unfortunately, war is a central feature of human civilization and will occur in spite of our feeble efforts to prevent it. The critical reality makes it necessary to adopt moral guidelines limiting the use of force for those who would undertake it. War is tragic and should be undertaken as infrequently and humanely as possible. Yet, war is also, at times, necessary. Thus, as Campbell (2007) put it, the employment of force needs to be limited by accepted moral principles; the role of the just war tradition. Campbell (2007) maintains that security and order are the primary objective of international politics which is the realist assessment of international relations and the behaviour of states. Secondly, a just war theory for the $21^{\text {st }}$ century must be minimalistic in order to be effective (Campbell, 2007).

According to Belter (2013) in his book the History of the Just War Theory, the moral issue here is war and the theory or set of principles that people look for justifying war is called the just war theory. He continues by simply defining those principles as follows:

"First: the justifying principles for why war is waged (jus ad bello) just cause; legitimate authority; right intention; proportionality; probability of success; last resort. Second are justifying principles governing conduct within war (jus in bello) proportionality; right intention; non-combatant immunity." (Belter, 2013) 
INTERNATIONAL JOURNAL OF ACADEMIC RESEARCH IN BUSINESS AND SOCIAL SCIENCES Vol. 10, No. 8, 2020, E-ISSN: 2222-6990 @ 2020 HRMARS

While war is hell, war is a reality in our world. Now tension exists between a hatred for war, it's inevitability, and a desire for peace. From that springs reasons to justify war, also called the just war theory. The theory is an attempt to humanize the dehumination of war. The theory is apparently nothing new. The Indian epic Mahabharata completed in the 400s BC, offers one of the first written discussion of what we know as the Just War Theory (Belter, 2013). In that epic, one of the five ruling brothers discussed with his uncle whether the suffering caused by war can ever be justified. In order to justify their war, they come up with some criteria such as proportionality "one should not attack chariots with cavalry; chariot warriors should attack chariots...one wounded should be given medical treatment in your realm"; just cause "war should be waged for the sake of conquest, one should not be enraged toward an enemy who is not trying to kill him"; and fair treatment of captives and the wounded (Schuman and Rieger, 1992).

Plato was the first Greek to talk about the idea of just war. Aristotle picked up on the topic and first used the term, just war. Roman philosophers like Emperor Marcus Aurelius wrote of his desire for peace and an exit from conflict and the awful nature of war, all while sitting on the front lines fighting to maintain peace (Estrella, 2012). It is the great church father, St. Augustine, Bishop of Hippo who is given credit for developing the foundation for just war theory and its first three principles: just cause; legitimate authority; right intention.

The Christians for decades had been the recipients of persecution: they lost land; freedoms; even their lives. Now Christians could begin to worship more freely. However even though the religion had been accepted, it and its people were still looked at with disdain by many. The reason being, the Roman Empire was in decline (Estrella, 2012). As Christianity became more and more the state religion and the ancient gods of Rome were pushed out, Rome seemingly began to crumble. Many pagan Romans attributed the fall of Rome to the fact that the Christian God was in charge now and failed to keep the empire safe as the old gods had done for so long. One other practical difficulty that arose for the emperors was how to maintain the Roman army, which for centuries was the backbone of Roman security and the Pax Romana, when many Christians would not or felt they could not serve (Hassner, 1944). They refused or were reluctant for two reasons: the first being, the Roman army had been the instrument of the Christians persecution and second, many early Church fathers preached pacifism (Hassner, 1944). They relied on Biblical passages such as Jesus' teaching of the "turn the other cheek" and his words to Peter "those who live by the sword will die by the sword" (Moran, 2001).

As pressure mounted from the north and the barbarian invasion became more and more an increasing problem and even threat to the safety of the empire and to the city of Rome itself, many Christians found themselves without clear guidelines and direction (Hassner, 1944). Can a Christian answer the Empire's call military duty and still have a clear conscience before God?

After Alaric I of the Visigoth sacked Rome in 410 AD, pressure against the Christian God and Christians grew and accusations abounded that Christians were too other worldly to be concerned citizens of the state (McMahan, 2004). In this complex political, military, and cultural environment, St. Augustine writes the City of God, a 22-volume work that he wrote from 413 to 420 AD, possibly 429 AD in which it is in that book that Augustine established that Christians could in good conscience assume the full obligations of citizenship, including participation in warfare (McMahan, 2004).

There are two cities according to Augustine: the Earthly City and the City of God. The priority for the Christian was to belong to the City of God and not to worry unduly about the City of Rome but focus on the City of God. Augustine's main goal for the Christian was to prepare them for heaven, 
to make sure their conscience was secure and at rest in Christ (Moran, 2001). Augustine's thoughts on the Earthly City are quite telling:

"The City of Man, for the most part, is a city of contention with opinions divided by foreign wars and domestic quarrels and by the demands for victories which either end in death or are merely momentary respites from further war" (Van Neste, 2006)

Augustine had an excellent grasp on Scripture and knew that while there were passages that seemed to speak of pacifism, a closer inspection revealed that war would be a reality in this world because of the corrupt nature of humanity.

"Any man who has examined history and human nature will agree that no human heart does not crave joy and peace. One has only to think of men who are bent on war. What they want is to win; their battles are but bridges to glory and to peace" (Belter, 2013)

Perhaps the biggest indication that Augustine gave for why a Christian could in good conscience participate in war was Romans 13.

"True religion looks upon as peaceful those wars that are waged not for motives for aggrandizement or cruelty, but with the objective of securing peace, punishing those who do evil and supporting the good"(Van Neste, 2006)

Augustine believes that war was never completely justified. Only Christ's war against evil was justified. Every war that is carried out is tainted by sin, no matter how just it maybe. There can never be an absolutely pure motive for carrying out war.

Yet Augustine made it quite clear that there were just reasons for carrying out war. The main reason to go to war was peace.

"Even when men are plotting to disturb the peace, it is merely to fashion a new peace nearer to the heart's desire...It is not that they love peace less, but that they love their kind of peace more...Thus, it is that all men want peace in their own society, and all want it in their own way. When they go to war, what they want is to impose on their enemies the victor's will and call it peace" (Van Neste, 2006)

The purpose of a just war, as opposed to an aggressive war fuelled by greed or ambition, is the pursuit of a better state of peace.

"Peace is not sought in order to provoke war, but war is waged in order to attain peace" (Gray and Gray, 2003)

Such wars are fought against tyrants or other power-hungry rulers that would threaten their neighbours. The pursuit of a better state of peace must therefore be for good cause. But also, in those statements Augustine made a distinction between the moral responsibility of the ruler who makes the decision for going into war and the moral conduct of the soldier in war. Those two should be distinguished for the sake of conscience.

"Therefore, a just man, if he should happen to serve as a soldier under a human king who is sacrilegious, could rightly wage war at the king's command, maintaining the order of civic peace, for what he is commanded to do is not contrary to the sure precepts of God...perhaps the iniquity of giving the orders will make the king guilty while the rank of servant in the civil order will show the soldier to be innocent" (Belter, 2013)

Augustine not only concerned with war, but also making sure members of the city of God reflected the moral qualities of that city and that their consciences were at peace with God. He emphasizes that a soldier has no say in the decision to go to war because war demands participation of those in 
INTERNATIONAL JOURNAL OF ACADEMIC RESEARCH IN BUSINESS AND SOCIAL SCIENCES

Vol. 10, No. 8, 2020, E-ISSN: 2222-6990 @ 2020 HRMARS

the military and requires that orders be obeyed (Belter, 2013). Then he relies on Paul's words in Romans 13:

"Everyone must submit himself to the governing authorities...for the authorities that exist are established by God" (Gray, 2003)

What matters then is the soldiers just conduct within war. Augustine saw war as a way to peace or the "common well-being" as he called it, what we might refer to today as national self-defence (Coverdale, 2004). Scatter throughout his writings, most especially throughout The City of God, we find the three foundational principles of just war theory; just cause, legitimate authority, and right intention.

Augustine's thoughts on just war are spread throughout his writings but were codified by the great Scholastic theologian, Thomas Aquinas in his Summa Theologica. He, like Augustine, was more concerned for Christians to live in a way that would honour God on earth and lead to an eternity in heaven.

Aquinas brought together writings of Aristotle and Augustine to put down three principles for entering a just war: just cause (those who are attacked because they deserve it), legitimate authority (by the command of sovereign who wages war) and right intention (advance good, avoid evil, achieve peace) (Belter, 2013). These are still at the heart of the just war debate in the $21^{\text {st }}$ century.

There are a couple of differences however, that Aquinas had in minds that are not part of the thought process of rulers today. Aquinas wrote:

"The secular power is subject to the spiritual, even as the body is subject to the soul" (Coverdale, 2004)

Like Augustine, Aquinas' intention was to provide an opportunity for Christians to express their faith and live in ways that lead to eternal life. His emphasis on right intention has implications for soldiers today. Aquinas wrote:

"The common good of many is more like Godlike than the good of an individual. Wherefore it is a virtuous action for a man to endanger even his own life, either for the spiritual or for the temporal common good of his country" (Coverdale, 2004)

What he meant is that when it came to a soldier in battle killing was not only acceptable but in the right circumstances was the ethical thing to do. In other words, the soldier who takes the life of another in battle or endangers his own life is carrying out a virtuous act because the intention in that case is an act of self-sacrificing love for a neighbour or for the good and preservation of country.

Aquinas would not however give the same provision to someone whose intention is to kill as many as possible regardless of whether those involved were waged in war or innocent bystanders.

"Wherefore if a man, in self-defence, uses more than necessary violence, it will be unlawful: whereas if he repel force with moderation his defence will be lawful, because according to the jurists...it is lawful to repel force by force, provided one does not exceed the limits of a blameless defence" (Belter, 2013)

The principles Aquinas wrote down are still used today, to guide countries going into war and the conduct of soldiers in war.

\section{Critics on Just War Theory}

\section{Realism}

Historically, realists have often argued that international relations is a Hobbesian state of nature that is also a state of war. Mapel (1998) states that the central claim of this notion is that morality should 
not always govern state conduct. This also forms the basis of a powerful challenge to more conventional ways of understanding the role of morality in international relation.

This challenge can be developed in three different ways, first is with respect to jus ad bellum, realism argues that strict observance of legal and moral prohibitions against aggression must sometimes compromise the state's security or survival. The second challenge would be with respect to jus in bello, realism argues that, that even wars fought for limited ends and with limited means must sometimes involve the deliberate killing of innocent people. The third challenge; some writers have insisted that both the ends and the means of war normally can and should be limited, but have argued that states are not bound to observe such limits in extreme situations.

Though realists have occasionally celebrated war, they have usually deplored it on the prudential grounds that war always poses a risk to the state (Mapel, 1998). This means, even the realists themselves recognized war as a mean of destruction that threatens the security and survival of state. Realists are sceptical about attempts to reconcile prudence and morality; they have often had a keen sense of immorality of war as well. In regards to Just War Theory, both realists and pacifists are sceptical about many of its distinctions. Firstly, some realists agree with pacifists that a consistent commitment to fundamental principles of common morality requires the rejection of war. However, they also argue that pacifism should be morally condemned because in refusing to use force to prevent the ruin of some, it allows the ruin of all. There is indeed a love hate relationship between these ideologies and war.

Realists think that war can in principle serve peace or justice by enforcing international law, by preserving a balance of power, or by promoting change. From a realist perspective, there are two objections to restricting the justification of war to self-defense. First, there is no clear way of limiting the definition of aggression, and therefore the idea of self-defense, without sometimes undercutting the claim of states to preserve their territorial integrity and political sovereignty. Secondly, it may at times prove necessary to wage wars that clearly go beyond self-defense, however defined, in order to protect national security.

In speaking of "just war", we speak not of justice but justification. Berkowitz (2013) argues that, that war is justified does not mean that it is just. What must be remembered is that within the theoretical context of just war theory, the word just is a term of art (Berkowitz, 2013). Berkowitz (2013) further writes that as a matter of justification, just war theory can and often does work to exclude and preclude the question of justice in war.

When used in the context of just war, justice "means justifiable, defensible, even morally necessary (given the alternatives) and that is all it means. For Walzer (1977), it is essential that in talking about just war we argue that "justice in the strong sense, the sense that it has in domestic society and everyday life, is lost as soon as the fighting begins." Orend (2006) writes that, what theories of just war address is not some high ideal of justice, but "a connected body of ideas and values which considers when war can be ethically justified." In short, a just war is a justifiable war and it is not necessarily bring justice to all. In other words, a just war is one that is seen to be legitimate when judged by clearly articulated norms, rules and legal principles.

While warfare is as ancient as mankind, the justification of wars is a uniquely modern idea. For Arendt (1970), the modern just-war theorizing that we encounter today is a response to the radical innovation in the violence of war witnessed in World War I.

"The notion that aggression is a crime and that wars can be justified only if they ward off aggression or prevent it acquired its practical and even theoretical significance," she writes, "only after the First 
World War had demonstrated the horribly destructive potential of warfare under conditions of modern technology" (Arendt, 1970)

The justification for war cannot proceed on utilitarian and rational grounds-the very idea of a useful war loses its purchase when the consequences of victory as much as defeat might mean annihilation (Arendt, 1970). What she means to express is that there is no such thing as justification for a just war if a nation is in total destruction at the expense of another nation's victory. There is no rational explanation to justify such outcome of war especially with rapid development of warfare modern technology.

Arendt (1970) writes that the very idea of just war is impossible for justice can only exist within laws. In modern times when wars always threaten absolute annihilation, the only justification left for war is the absolute justification: we fight for freedom and for existence itself.

"In other words," she writes, "freedom has appeared in this debate (over the justification of war) to justify what on rational grounds has become unjustifiable" (Arendt, 1970)

Just war theory emerges as a theory of justification, in other words, precisely when the usual justifications of rationality and utility cease to function as meaningful justifications of war. We must recognize, therefore, that just war theory is above all an effort to justify and rationalize war at a time when war is ever more difficult to justify.

The effort to justify, rationalize and humanize war, however, is something far different from the demand to do justice. In an age when war is carried out in cities, when wars are fought against guerrilla and non-state actors, and when the line separating civilians from soldiers is blurred, the effort to justify war is as likely to authorize the killing of innocents as it is to restrain it. The rise of lawfare means that the demand to legalize and justify war carries with it the need to normalize war. This is true both in the sense that war is subordinated to legal and moral norms, and also in so far as war is regularized and tamed. On the other hand, such a radical pacification of war is impossible. War like any deeply human activity, will exceed all efforts by humans to control and to regulate it. On the other hand, the desire to normalize war is also misplaced. What is needed, rather, is a determination to recall that justice, and not merely justification, has a place in war.

\section{Pacifism}

Just war theory emerges in opposition to pacifism. For pacifists, any recourse to armed conflict endangers the soul and contradicts the imperative of peace (McShane, 2012). Even as just war theory agrees with pacifists that war must not be a common solution to everyday political disagreements, it diverges from pacifism in accepting that war is, at times, a both justified and necessary (Coverdale, 2004). Just war theory believes that all war is potentially justifiable-at least under certain conditions.

The connection between pacifism and just war theory goes back to the very origin of the just war tradition. For early Christians, the Bible offered a number of statements that were thought to command an unremitting pacifism (Coverdale, 2004). Jesus teachings were thought by many Christians to forbid war as well as to disqualify Christians from military life. It was in response to such pacifist sentiments that St. Augustine first enunciated a response that was designed to authorize Christians to fight and wage wars while at the same time insisting that those wars accord with Christian morality.

Augustine offered "a workable ethical guide for the practicing Christian who also had to render unto Caesar his service as a soldier" (Gray and Gray, 2003). Augustine's approach to just war was in the form of a discussion of the conditions are less a theoretical system than simply a guide of those 
good reason a state has for going to war. Augustine argues war can be for just reasons, but if so it must be for the end of peace; it must be fought with a "pacific intention", that governs both the decision to engage in war and the means by which one fights (Gray and Gray, 2003). Augustine's efforts to overcome Christian pacifism and to articulate theory of just war is one main root of the tradition of just war theorizing as it have developed over the last 1600 years.

The second historical foil for just war theory is the tradition of political realism, the idea that, in Cicero's formulation: in war, the laws are silent (Bellamy, 2006). If pacifism insists that all wars are unjust, realism claims that war is as a moral activity that can be neither justified nor judged in accordance with moral standards. Realists accept that "states simply do not care about morality and justice; they only care about their own interests." Moral concepts, the reality holds, are literally inapplicable to the realm of foreign affairs.

For realists, "war is simply an act of politics by other means," as Karl Von Clausewitz so famously argued; war is an act of force...which theoretically can have no limits (Underwood, 2009). The unlimited nature of war-that it is a fight to the death for ultimate values including life and liberty themselves-means that the only logic of war is victory and "there can be no imaginable act of violence, however treacherous or cruel, that falls outside of war, that is not-war, for the logic of war simply is a steady thrust toward moral extremity (Underwood, 2009).

The logical push of war towards extremes imagined by realist is only more apparent in our age, for at least two reasons; first the technology of destruction in modern war is so extraordinary that we threaten not just defeat but annihilation. In the age of night flights, carpet bombing, suicide bombings, and nuclear weapons, the modern menace is a "total annihilation that extends to the child in the cradle, who is threatened like everyone else- even more so" (McShane, 2012). Secondly, the extremity of the war today is even more deeply rooted in its democratic spirit; wars are fought no longer simply by armies, but require a mobilization of an entire civilization-a civilization that is threatened with destruction should it suffer defeat (Underwood, 2009). According to Thurmond (2006), this "total mobilization" - includes industry, agriculture, and most importantly, the masses in modern wars, the distinctions between soldier and civilian, munitions and chemicals, weapons system and the electricity grid are blurred if not rendered moot, and the ethical attempt to limit the reach of war fly in the face of war's reality.

If realists have always understood war as "a world apart", one that is immune to moral considerations, they are right today that the complexity and totality of war overruns moral and political limits (Thurmond, 2006). Realist like Hans Morgenthau argues that to impose morality on war is like making a category for mistake. Realism thus challenges the fundamental assumption of Just War Theory, that justice is a reliable metric with which to evaluate war. Between the pacifists' extreme moral rejection of war and the realists' extreme ejection of war from the moral universe, the just war tradition insists that wars will happen, and they must be subjected to moral judgment. For Walzer (1977), the just war theorists must come to grips with the fact that their rules are often violated or ignored.

\section{Legalism: The International Law}

Much of the effort at justifying war today seeks to find the relevance and effectiveness that philosophical just war arguments lack by couching its arguments in a practical legal vocabulary. Gilson ( 2011) states that the attraction of international law is to subject war to "a set of objective rules" that would determine when wars are justified. 
INTERNATIONAL JOURNAL OF ACADEMIC RESEARCH IN BUSINESS AND SOCIAL SCIENCES Vol. 10, No. 8, 2020, E-ISSN: 2222-6990 @ 2020 HRMARS

From the League of Nations and the Kellogg Briand Pact of 1928 to the Rome Statute of the International Criminal Court of 2002, international law has institutionalized the idea that decision making about war should adhere to a set of objective normative standards (Underwood, 2009). For Reichberg (2006) this development is merely the culmination of a long process of moral and legal reflection that reaches back to the Christian Middle Ages. For Dinstein (2004), the rise of an international law of war is $20^{\text {th }}$ century innovation beginning with the Kellogg Briand Pact of 1928 has been a watershed in the legal regulation of the use of inter-state force.

\section{Conclusion}

Most of these writers of books and journals provided an excellent explanation of what is just war theory and the purpose of just war theory. However there is always this question of how war can be moral by looking at how devastating the nature of war is. Of course, many philosophers attempted to answer this question and then again spark new questions. Since just war theory is developed when waging war is simpler, using sword and horses, many question how just war is going to tackle the more modern tactical aspect of war, obvious example would be the weapons of mass destruction where there is no clear line of who is who, arises. By looking at all these aspects, it is very clear for political philosophers that their work is not yet done.

The emphasis on moral guidance in conducting war should be applauded and supported because history proves that there is necessary war, for example war toward tyranny and war for self defence against outside interference. However, this moral guidance can be manipulated to wage war for personal gain and war to inflict pain and destruction in the name of self-defence. The so-called preventive war or pre-emptive war is highly questionable in many aspects and most of them clearly not justified. Here, the question would be, should we justify war. Some war clearly against just war theory, but who is going to stop this unjustified war. So what is the use of justifying the war if there is no immediate effect or legal side of it?

The principles of just war theory, jus ad bellum and jus in bello have been playing a crucial role in defining war, justified or not. Of course, these principles have been updated parallel to modern need, but are not enough. Not to mention the most recent development of just war theory, jus post bellum, is always below the radar and lightly discussed because of its application after the war. It is still not clear how war can be deemed justified by using these principles. Should these principles be followed by its order, jus ad bellum, jus in bello and jus post bellum for war to be justified, or war to fulfil some of the requirements of these principles to be justified? Are these principles used to legalize or moralize war is another big question. This research is needed so that we can explore this unexplored side of just war theory.

\section{References}

Allman, M. J., \& Winright, T. L. (2007). Faith in Public Life: Jus Post Bellum Extending the Just War Theory. The Annual Publication of the College Theology Society, 53(1)

Arendt, H. (1970). On Violence. Florida: Houghton Mifflin Harcourt.

Bass, G. J. (2004). Jus Post Bellum. Philosophy \& Public Affairs. 32(4).

Bauer, J. W. (2006). A Problem for Military Ethics During Irregular War. War Monograph (2006), 8-10

Belter, J. (2103). The History of the Just War Theory, Pastor's Conference of the South- Central District: Redeemer Lutheran Edna. 
INTERNATIONAL JOURNAL OF ACADEMIC RESEARCH IN BUSINESS AND SOCIAL SCIENCES

Vol. 10, No. 8, 2020, E-ISSN: 2222-6990 @ 2020 HRMARS

Bellamy, A. J. (2006). Just Wars: From Cicero to Iraq. Cambridge, UK: Polity.

Berkowitz, R. (2013). Should We Justify War. Just War in Religion and Ethics.1(21), Bard College:

University Press of America.

Bettenson, H. (1984.) St. Augustine, Concerning the City of God Against Pagans. Penguin Books

Boelaert-Suominen, S. (2000). International Environmental Law and Naval Law: The Effect of Marine Safety and Pollution Conventions during International Armed Conflict. Newport, R.I.: Naval War College Press.

Booth, K. (2007). Theory of World Security, New York: Cambridge University Press.

Brabandere, E. D. (2010). The Responsibility for Post-Conflict Reforms: A Critical Assessment of Just Post Bellum as a Legal Concept. Vanderbilt Journal of Transitional Law.

Burke, A. (2004). Just War or Ethical Peace? Moral Discourses of Strategic Violence After 9/11. International Affairs. 80(2): 329-353

Cable, J. (1954). The Geneva Conference of 1954 on Indochina. London: Macmillan Press Ltd

Campbell, L. B. (2007). Just War, Legitimate Authority and Non-State Actors, Missouri: William Jewel College.

Caplan, R. (2005). International Governance of War-Torn Territories: Rule and Reconstruction. Oxford Scholarship Online. Oxford University Press.

Carr, E. H. (1981). The Twenty Years' Crisis,1919-1939, London: Macmillan.

Chandler, D. P. (1991). The Tragedy of Cambodian History: Politics, War, and Revolution Since 1945. New Haven: Yale University.

Chesterman, S. (2004). You, the People: The United Nations, Transitional Administration and StateBuilding, 258. Oxford Scholarship Online.

Christopher, P. (1999). The Ethics of War and Peace, New Jersey: Prentice-Hall

Chroust, A. H., \& Osborn, D. L. (1942). Aristotle's Conception of Justice. Notre Dame L.Rev.17(2). Retrieved from http://scholarship.law.nd.edu/ndlr/vol17/iss2/2

Clark, I. (2005). Legitimacy in International Society. Oxford: Oxford University Press.

Clausewitz, C. V. (1982). On War, London: Penguin.

Coates, A. J. (1997). The Ethics of War, Manchester: Manchester University Press.

Coverdale, J. F. (2004). An Introduction to the Just War Theory. Pace International Law Review. 16(2), p. s222-276

Cummiskey, D. (2008). Justice and Revolution in Kant's Political Philosophy. Rethinking Kant-Current Trends in American Kantian Schlarship. Cambridge: Scholar Publishers.

Day, G. (1998). Policekeeping' Critical to Rebuilding Iraq. Policing the New World Disorder: Peace Operations and Public Security. Washington DC: National Defense University Press.

Derian, J. D. (2000) Virtuous War/Virtual Theory. Royal Institute of International Affairs.Vo.76, No.4:771-788

Dierksmeier, C., \& Anthony, C. (2014). Thomas Aquinas on Justice as a Global Virtue. Research Paper Series, Humanistic Management Center, accessed January 282014.

Dinstein, Y. 2004. The Conduct of Hostilities Under the Law of International Armed Conflict. UK: University Press Cambridge.

DiMeglio, R. P. (2005). The Evolution of The Just War Tradition: Defining Jus Post Bellum. Military Law Review. 6(1), p. 67-84

Douglass, J. (1968). The Non-Violent Cross, London: Geoffrey Chapman. 
INTERNATIONAL JOURNAL OF ACADEMIC RESEARCH IN BUSINESS AND SOCIAL SCIENCES

Vol. 10, No. 8, 2020, E-ISSN: 2222-6990 @ 2020 HRMARS

Doyle, J. P. (1997). Francisco De Vitoria, O.P.:Reflection on Homicide \& Commentary on Summa Theologiae Q.64 (Thomas Aquinas). Trans. Milwaukee: Marquette University Press.

Doyle, M. W. (1995). UN Peacekeeping in Cambodia: UNTAC's Civil Mandate. Colorado: Lynne Rienner Publishers.

Ellis, A. (2001) What Should We Do with War Criminals? War Crimes and Collective Wrongdoing: A Reader. Cambridge: Blackwell.

Elshtain, J. B. (2004). The Just War Tradition and Natural Law. Fordham International Law Journal, 28(3), 1-16.

Estrella, I. A. E. (2012). On the Ethics of War. Kritike, 6(1), 67-84.

Feldman, O. \& Christ'I L. (1998). Post-Realism, Just War, and the Gulf War Debate. Westport CN: Praeger.

Fixdal, M. \& Dan S. (1998). Humanitarian Intervention and Just War. Mershon International Studies Review, 42(2), 283-312.

Franck, T. M. (2002). Recourse to Force: State Action Against Threats and Armed Attacks. United Kingdom: Cambridge University Press.

General Assembly Restitution. (2005). 60/180. UN DOC. A/RES/60/180

Gilson, T. (2011). Just War and Preventive Force Doctrines: An Ethical Analysis of Opposites. SPNHA Review. 7(1), 13-20. Grand Valley University.

Glennon, M. J. (2003). Why the Security Council Failed. Foreign Affairs. 85(5).

Goldstein, C. S. (2012). Just War Theory and Democratization by Force: Two Incompatible Agendas. Military Review. 92(5), 2-9.

Graham, D. E. (1975.) The 1974 Diplomatic Conference on the Law of War: A Victory for Political Causes and A Return to the "Just War" Concept of the Eleventh Country. Washington and Lee Law Review. 32(1), 1-41.

Hassner, P. (1944.) Beyond the Three Tradition: The Philosophy of War and Peace in Historical Perspective. Royal Institute of International Affairs. 70(4), 737-756

Hastie, W. (2003). Trans. Immanuel Kant, The Philosophy of Law: An Exposition of the Fundamental Principles of Jurisprudence as the Science of Right. Edinburgh: Lawbook Exchange.

Heinze, E. A. \& Brent, J. S. (2009). Ethics, Authority, and War: Non-State Actors and the Just War Tradition. New York: Palgrave Macmillan.

Hill, S., \& Malik, S. (1996). Peacekeeping and the United Nations. Brookfield, Vermont: Dartmouth Publishing Company.

Himes, K. (2004). Intervention, Just War, and U.S National Security. Theological Studies. 65(1), 141157.

Holiday, D., \& Stanley, W. (1993). Building the Peace: Preliminary Lessons From El Salvador. Journal of International Affairs. 46(2).

Iasiello, L. (2004). Jus Post Bellum: The Moral Responsibilities of Victors in War. Naval War College Review. 57(38).

Johnson, J. T. (2006). The Just War Idea: The State of The Question. USA: Rutger University.

Jubilut, L. L. (2010). Towards a New Jus Post Bellum: The United Nations Peacebuilding Commission and the Improvement of Post-Conflict Efforts and Accountability. Minnesota Journal of International Law.

Kellogg, D. (2002). Jus Post Bellum: The Importance of War Crimes Trials. Parameters. 32(3), p. 93. Kennan, G. (1984). American Diplomacy, Chicago: University of Chicago Press. 
INTERNATIONAL JOURNAL OF ACADEMIC RESEARCH IN BUSINESS AND SOCIAL SCIENCES

Vol. 10, No. 8, 2020, E-ISSN: 2222-6990 @ 2020 HRMARS

Kiernan, B. 2008. The Pol Pot Regime: Race, Power and Genocide in Cambodia under the Khmer Rouge, 1975-79.

Kiljunen, K. (1986). Report of a Finnish Inquiry Commission, Kampuchea: Decade of Genocide. Totowa, N.J: US Distributor

Kissinger, H. A. (1957). Nuclear Weapons and Foreign Policy, New York: Harper.

Kissinger, H. A. (1971). White House Years, Boston: Little Brown \& Co.

Kissinger, H. A. (1991). America Cannot Police the World Forever. The Times, 12 March 1991

Kleiderer, J. (2006.) War and Peace: Parallel Traditions. Just War, Lasting Peace: What Christian Traditions Can Teach Us. Maryknoll, NY: Orbis Books.

Malone, D. M., \& Thakur, R. (2001). UN Peacekeeping: Lessons Learned. 7 Global Governance II. 12

Mapel, D. R. (1998). Realism and the Ethics of War and Peace. The Ethics of War and Peace, ed. Terry Nardin et al. 54-77, New Jersey: Princeton University Press.

Maogota, J. N. (1999). From Congo to East Timor in Forty Years: The UN Finally Crossing the Rubicon Between Peace Keeping and Peace Making. Newcastle Law Review. 45, 46-47

Marks, S. P. (1994). The New Cambodian Constitution: From Civil War to a Fragile Democracy. Colum. Hum. Rts. L.Rev.26

McMahan, J. (2004). The Ethics of Killing in War. Ethics 114 University of Chicago. 693-733

McMahan, J. (2006). Preventive War and the Killing of the Innocent. The Ethics of War: Shared Problems in Different Traditions, p.172. Ed. Richard Sorabji \& David Rodin. Aldershot: Ashgate.

McCoubry, H. \& White, N. (1992). International Law and Armed Conflict. Cambridge University Press.

McShane, T. W. (2012). In Search of the Good War: Just War and Realpolitik in Our Time. Military Review. 92(5), 9-18.

Mednicoff, D. M. (2006). Humane Wars? International Law, Just War Theory and Contemporary Armed Humanitarian Intervention. Law, Culture and Humanities. 2(1), 373-398.

Montgomery, B. L. (1958.) Memoirs, London: Collins.

Moral, D. (2001). Strategic Theory and the History of War. Newport Rhode Island: Princeton Institute of Advanced Study.

Neff, S. (2005). War and the Law of Nations: A General History. Cambridge University Press.

Neste, B. V. (2006). Cicero and St. Augustine's Just War Theory: Classical Influences on A Christian Idea. Graduate School Theses and Dissertations University of South Florida. 49-60

Nivat, A. (2005). The Wake of War: Encounters with the People of Iraq and Afghanistan, trans. Jane Marie Todd. Boston: Beacon Press.

O'Connor, V. (2006). Rule of Law and Human Rights Protections through Criminal Law Reform: Model Codes for Post-conflict Criminal Justice. International Peacekeeping. 13(4), p. 517.

O'Neil, S. (1999). Rethinking the United Nation's Role in Peacekeeping: Lesson From El Salvador. Journal of Public and International Affairs. 10(1). Princeton University.

Oppenheim, L. (1906). International Law: A Treatise. London: Longmans, Green and Co. p. 280-98.

Orend, B. (2000). Jus Post Bellum. Journal of Social Philosophy. 31(1), p. 128

Orend, B. (2002). Justice after War. Ethics and International Affairs. 61(1), p. 46

Orend, B. (2007). The Rules of War. Ethics and Internatinal Affairs. 21(4), 471-476.

Orend, B. (2008). Jus Post Bellum: A Just War Theory Perspective. Asser Press, The Hague, The Netherlands and the Authors. Carsten Stahn \& Jann K. Kleffner (eds,) Jus Post Bellum. 
INTERNATIONAL JOURNAL OF ACADEMIC RESEARCH IN BUSINESS AND SOCIAL SCIENCES

Vol. 10, No. 8, 2020, E-ISSN: 2222-6990 @ 2020 HRMARS

Orend, B. (2006). The Morality of War. Broadview Press.

Orwell, G. (1962). Inside the Whale And Other Essays, London: Penguin.

Paris, R. (2007). Post-conflict Peacebuilding. Oxford Handbook on the United Nations. Oxford University Press.

Peacebuilding Commission Agenda. (2010), September 24. UN Peacebuilding Commission. http://www.un.org/peace/peacebuilding/pbcagenda.shtml

Rapp, A., \& Phillip, C. (1995). Conflicts Cambodia/Campuchea. In R. Wolfrum (eds). United Nations: Law, Policies and Practice. 1(200).

Rawls, J. (1999). A Theory of Justice, rev. Ed. Cambridge, MA: Harvard University Press.

Reichberg, G. M. (2006). The Ethics of War: Classic and Contemporary Readings. USA: Blackwell Publishing.

Reichberg, G. M. (2013). Forcible Preventive Disarmament in Traditional Just War Theory. Pontifical Academy of Social Sciences. 18(1).

Rengger, N. (2002). On the Just War Tradition in the Twenty-first Century. International Affairs. 78(2), 353-63

Representative of the High-Level Panel of Threats, Challenges and Change. (2004), December 2. A More Secure World: Our Shared Responsibility. UN DOC. A/59/565

Rychlak, R. J. (2004). Just War Theory, International Law and the War in Iraq. Ave Maria Law Review. 2(1), 1-47.

Scheers, I. (2011). Peacekeeping and Jus Post Bellum: Towards a Concept of Rules in Post-Conflict Situations. CEJISS, 5(3).

Schuman, H., \& Rieger, C. (1992). Historical Analogies, Generational Effects, and Attitudes Towards War. Americal Sociological Review, 57, 315-326

Scott, J. B., et. al. (1925). On the Law of War and Peace. The Classics of International Law, 9(52).

Simonovic, I. (2003). Post-conflict Peace Building: The New Trends. INTL. J. Legal INFO, 31.

Stahn, C. (2007). Jus Post Bellum: Mapping the Discipline(s). American University International Law Review 23(2), 311-347.

Stahn, C. (2007). 'Jus ad bellum', 'jus in bello'...'jus post bellum'?-Rethinking the Conception of the Law of Armed Force. The European Journal of International Law, 11(5).

Schuck, M. (1994). When the Shooting Stops: Missing Elements in Just War Theory. The Christian Century. 982-83

The Secretary-General. (2004). Report of the Secretary-General on the Rule of Law and Transitional Justice in Conflict and Post-Conflict Societies. UN DOL.5/2004/616

Thurmond, A. (2006). Terrorism in the Age of Just War Thinking. Thesis for Art Department. Louisiana State University. 12-15

Tolstoy, L. (1991) War and Peace, Oxford: Oxford University Press.

Underwood, M. R. E. (2009). The Moral Reality of War: Defensive, Force and Just War Theory. Philosophy Theses. 53, 20-42

U.S Navy Dept. (1997). Annotated Supplement to the Commander's Handbook on the Law of Naval Operations, Oceans Law and Policy. NWP 1-14M/MCWP 5-2.1/COMDTPUB P5800.1. Newport R.I.: International Law Dept., Center for Naval Warfare Studies, Naval War College. 5-7

Walzer, M. (1977). Just and Unjust Wars. New York: Basic Books 
INTERNATIONAL JOURNAL OF ACADEMIC RESEARCH IN BUSINESS AND SOCIAL SCIENCES

Vol. 10, No. 8, 2020, E-ISSN: 2222-6990 @ 2020 HRMARS

Walzer, M. (2006). Just and Unjust Wars: A Moral Argument with Historical Illustrations, New York: Basic Books

Westerman, D. (2006). Depleted Uranium-Far Worse than 9/11.

http://www.globalresearch.ca/index.php?context=viewArticle\&code+20060503\&articleld=2

374

Zahn, G. (1991). An Infamous Victory. Commonweal. 8-366 